\title{
ASSESSMENT OF THE BIOGAS PRODUCTION POTENTIAL WITHIN THE SLOVAK SPIRITS INDUSTRY
}

\author{
Ondrej Beňuš*, Peter Bielik, Natália Turčeková, Izabela Adamičková
}

\author{
Slovak University of Agriculture in Nitra, Slovakia
}

\begin{abstract}
The Slovak spirits industry has a stable position within the alcoholic beverages industry in the Slovak Republic. However, its production process causes significant environmental stress on nature. The industry can use roughly only $10 \%$ of the raw materials. This means a significant amount of waste is produced during the distillation process. We investigated the biogas production potential within the Slovak distilleries producing spirits for final consumption when we compared the production of spirits between the years 2010 and 2019. Biogas production potential is calculated as an ideal situation when all spent wash from spirits producing distilleries is used for biogas production. The potential energy gain is also calculated in kWh based on the already available research in the field of biogas production. We conducted that the total biogas potential of the Slovak spirits industry could reach $15,886,053 \mathrm{kWh}$ in terms of electricity and 22,946,177 kWh in terms of heat energy if we calculate energy potential according to the spirits production in the year 2019. The total combined energy potential generated during the reuse of waste from distilleries could reach $38,832,230 \mathrm{kWh}$. The biogas production in these facilities has also a positive side effect. If distilleries use the heat energy for the distillation process, the amount of greenhouse emissions will also be declining.
\end{abstract}

Keywords: spirits industry, waste production, biogas

\section{Introduction}

The spirits industry represents a traditional branch of the food industry. The mass production of spirits was enabled by continuous spirits production in the $12^{\text {th }}$ century (Hartmann and Schwarz, 2018). Industrial distilling grew rapidly during the industrial revolution in the $18^{\text {th }}$ century. There were 674 commercial distilleries in the territory of the current Czech and Slovak Republic in 1848 (Nydrle, 1920). The raw material for their production varied. In the territory of the Slovak Republic, there was a relatively high emphasis on different varieties of fruit. The simple fermentation process and favourable climate (in most of the territory) secured cheap processing cost for spirits production.

With the collective ownership, new pathways were drawn by policymakers in 1945. Significant changes occurred also in the distilling industry within our territory. Small distilleries were integrated into large legal entities. This allowed broader use of modern approaches to spirits production, and the use of starch-based raw materials started to be a dominant source of spirits production (Grégr, 1974).

Nowadays, the spirits industry has a stable position within all countries of the world. The alcoholic beverages are projected to achieve revenues of 1,665.7 billion USD in 2021 (Statista, 2021) when the spirits industry alone will contribute to the above-mentioned revenues by 507.5 billion USD with estimated revenue growth of 7.8\% (Statista, 2021). Within the EU, there were 7411 enterprises distilling spirits and generating 29.6 billion EUR in revenues in 2018 (Eurostat, 2021). These distilling enterprises have also a strong presence in the European labour market as they employed 61,134 employees in 2018 (Eurostat, 2021). The spirits production has a strong position within the Slovak Republic, too. There were 119 companies distilling spirits with a production value of 87.8 million EUR in the Slovak Republic in 2018 (Eurostat, 2021).

The spirits industry has also a significant role in waste production when compared to other branches of the food industry. This contrasts with objectives of the $\mathrm{EU}$ in the field of green and sustainable economy.
The New Circular Economy Action Plan, first introduced by the EU on March 13,2020 , emphasises the reuse of waste produced during manufacturing processes and adding value to the waste use (European Commission, 2021). This may create even a higher demand for production efficiency and spent wash reuse within the distilling industry. The average efficiency of spirits production is growing due to the new modern technology application and the use of the latest research. Despite this enormous effort, there is still around $90 \%$ of raw resources unused. This problem has been emphasised by various authors in both older and the newest research. The first and the simplest research was dedicated to direct utilization of the spent wash on the arable soil (Stehlík, 1981). A more modern approach already focuses on the sustainable reuse of waste produced during the distillation of spirits in distilleries (Dhote et al., 2020). This sustainable reuse of waste is primarily oriented on the production of energy before it will be definitively used as a fertilizer on the arable soil.

The production of bioenergy has been in the research forefront for decades now. The first attempts focused on the direct use of scarce resources in the form of corn, wheat, rye, or silage (Rabeya et al., 2020, Makutenas et al., 2018, Barrière et al., 2016). The use of the mentioned sources has obvious disadvantages which were already well documented in the available literature (Lajdová et al., 2017). The overall energy gain from these biofuels has been doubted in the research when compared to second- and thirdgeneration biofuels (Lorenz and Morris, 1995; Pimentel and Patzek, 2005). It is obvious that the use of cereals, silage, or other similar products to produce biofuels creates competition with their primary role as main ingredients in the nutrition of humans. The second generation of biofuels brought the orientation of raw materials that do not compete directly with food production (Hirani et al., 2018). The production of biofuels is more oriented on cellulosebased products that are grown on land not suited for cereal production, cereal growing by-products that would be otherwise wasted or used as a fertilizer on the arable land. The third and the most recent generation of biofuels brought the use of algae to the centre of interest. The main objective is to further lower production cost and protect arable land for other uses (Neto et al., 2019). 


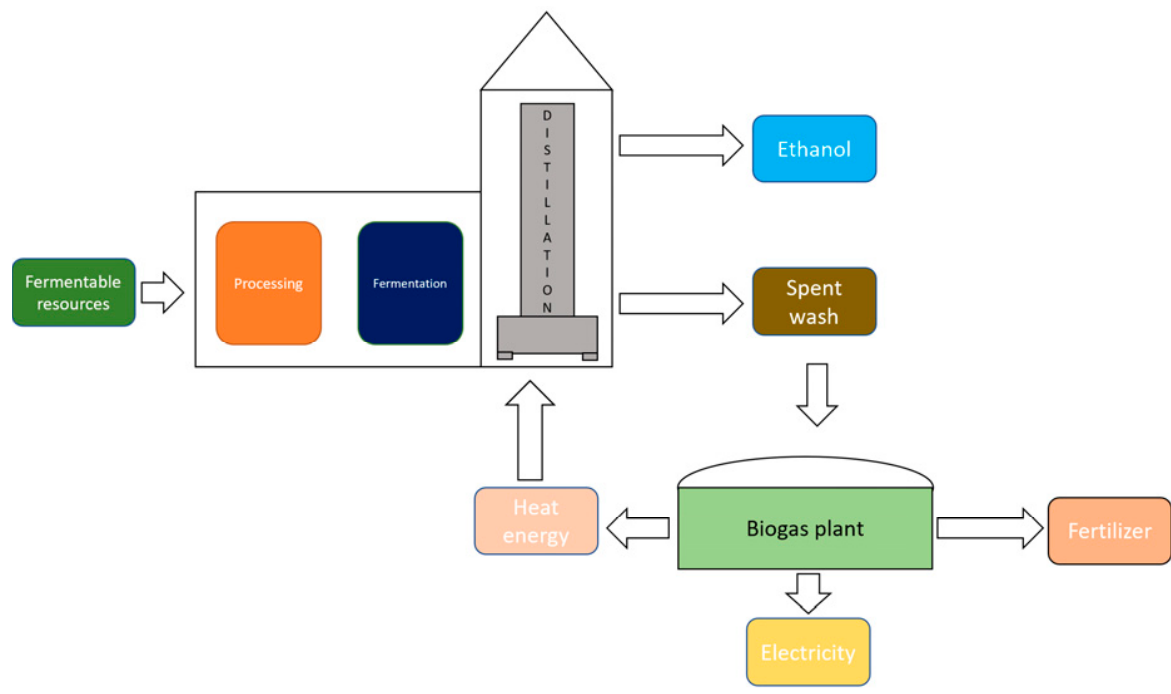

Figure 1 Example of biogas plant utilization in a distillery

The most obvious reuse option for spent wash from distilleries occurs to be the biogas production. Biogas plants do not use inputs that would directly compete with food production, in most cases. The feasibility of biogas plants using various sources of the waste product have been well examined in various research (Čeryová et al., 2019; Koval et al., 2019).

The first research oriented on the feasibility of biogas production in distilleries started directly after the Velvet revolution in the Slovak Republic in 1989. The research was mainly oriented on sugar molasses reuse and its energetical potential. According to this early investigation, a high energetic potential was determined in distilleries in the Slovak Republic (Jeníček et al., 1994).

Nowadays, with production costs on the rise and countries strengthening their policies on sustainability and green economy, distilleries are trying to apply new approaches to their production and waste utilization (The Spirits Business, 2021). As a result, numerous biogas plants were employed to process spent wash from distilleries. Scotch distilleries have been implementing the site biogas production in recent years (Filtration + Separation, 2016). These manufacturing enterprises saw additional benefits of biogas production. The energy supply in remote areas of Scotland is often insufficient and energy supply shortages are very often. By adopting biogas production, many Scotch distilleries gained autonomy in energy supply in almost $80 \%$ of their total energy demand (Duguid and Strachan, 2016). The latest research also emphasises reducing greenhouse gas emissions in distilleries when adopting biogas production on their premises (0'Shea et al., 2020).

\section{Material and methods}

We focused on the assessment of the biogas production potential in the Slovak spirits industry. Our research is based on the available data identifying the yearly production of spirits within the Slovak Republic. We investigated only ethyl alcohol made to produce spirits used for human consumption, but distilleries cover a much wider scope of products (ethyl alcohol is also used in pharmacy, chemistry, transportation etc.).

We calculated the annual spent wash production according to the amount of spirits produced by the Slovak spirits industry. We assumed the waste production using available data for the production of spirits and the

Table 1 Biogas production from various types of the spent wash

\begin{tabular}{|l|c|}
\hline Type of spent wash & Biogas production $\left(\mathrm{m}^{3} / \mathrm{m}\right)$ \\
\hline Sugar molasses & 30 \\
\hline Potatoes & 36 \\
\hline Wheat & 38 \\
\hline Rye & 40 \\
\hline Corn & 45 \\
\hline
\end{tabular}

estimated waste production based on the already available research in this field (Gleixner, 2004). The amount of spent wash usable for the biogas production was estimated according to the following formula:

$$
W_{\text {us }}=S_{\text {tot }} \times R_{\text {agri }} \times e f \times G
$$

where:

$W_{u s}$ - usable spent wash produced per year

$S_{\text {tot }}$ - total spirits production per year

$R_{\text {agri }}$ - amount of agricultural resources needed to produce one unit of spirits in a distillery

ef - efficiency of the distillation process when producing spirits

$G \quad$ - percentual amount of spent wash assigned as a waste in a distillery

We used the annual production of usable spent wash to calculate the energy potential of the biogas production based on the following equation:

$$
B G_{\text {annual }}=W_{u s} \times B G_{\text {eff }} \times \eta
$$

where:

$B G_{\text {eff }}$ - biogas production per one unit of spent wash

$\eta \quad$ - efficiency of energy production (heat or thermic)

Statistical data used in our research are from the following sources:

$\square$ Ministry of Agriculture and Rural Development of the Slovak Republic,

\section{$\square$ Eurostat.}

Our observations and calculations are limited exclusively to the territory of the Slovak Republic and the time frame of the research is restricted to the ten years starting in the year 2010 and ending in the year 2019.

\section{Results and discussion}

The Slovak spirits industry has a stable position within the overall consumption of alcoholic beverages within the Slovak Republic. Despite this fact, there is an overall tendency toward a lower consumption of spirits, especially among the young generation. This trend has also affected spirits consumption in the Slovak Republic in the last ten years. However, consumption of spirits in the Slovak Republic is still above the average of the EU. On the other side, citizens of the neighbouring countries prefer drinking alternative alcoholic beverages such as wine (Hungary) or beer (Czech Republic). 


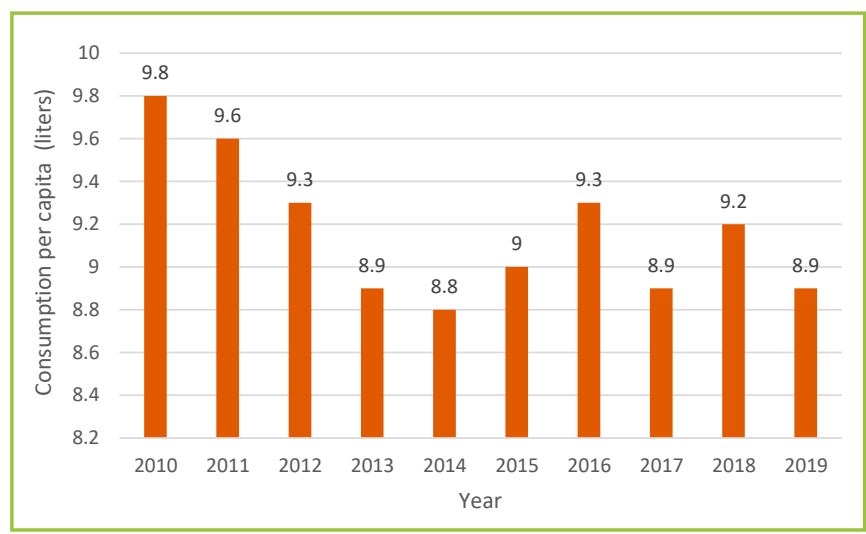

Figure 2 Spirits consumption per capita in the Slovak Republic between the years 2010 and 2019

Compared to the stagnation of spirits consumption, the production of spirits seems to be on the growth in the Slovak Republic, especially from the year 2015 (Figure 3). The overall production of spirits grew by $8.66 \%$ between the years 2015 and 2020. This growth in production helped to generate additional revenues within this industry when the turnover grew by $43.6 \%$ in the mentioned five years (Eurostat, 2021).

This growth of production also caused more waste produced by these enterprises. Thus, we found that our objective to investigate waste production and its potential use might have an even higher potential in the future in the case of even higher production of spirits.

We investigated spirits production between the years 2010 and 2019 in our research. Based on available research, we estimated the total spent wash production by this industry in the Slovak Republic. According to previous research (Gleixner, 2004), the average waste to product ratio is $10: 1$. One litre of the final product creates roughly ten times more waste. However, the total amount of spent wash does not equal to final unusable waste. Distilleries to improve efficiency and homogeneity of the product reuse about $40 \%$ of the spent wash. Based on all the above-mentioned assumptions we calculated usable spent wash for biogas production (Table 2.).

The total spent wash usable as input for biogas production grew from $89,533.78$ tsd. litres in the year 2010 to $103,323.92$ tsd. litres in the last observed year 2019. Waste production may grow in the future. This could lead to higher biogas production potential in spirits distilleries in the Slovak Republic.

We decided to investigate biogas production in all investigated years separately. Firstly, we calculated potential biogas production according

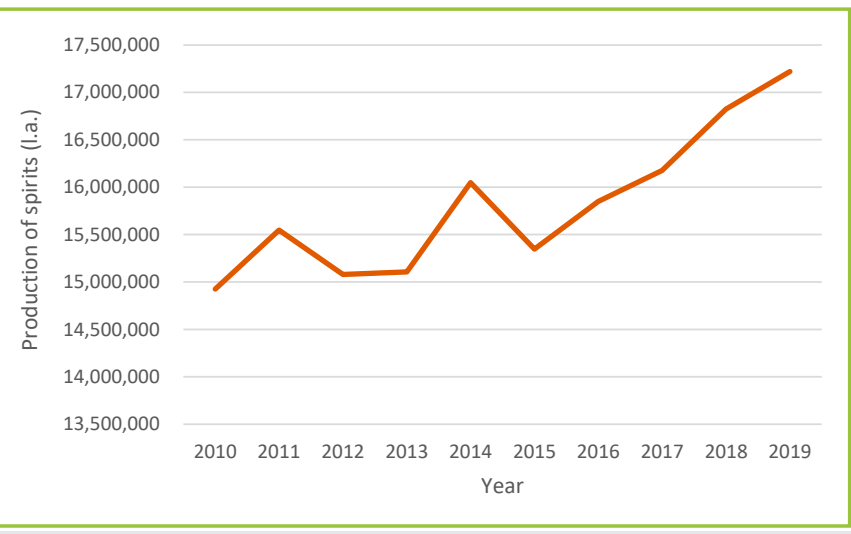

Figure 3 Spirits production in the Slovak Republic between years 2010 and 2019

to different raw materials processed in spirits distilleries. We estimated only biogas production from different agricultural materials. According to the Regulation 110/2008 of the European Parliament and of the Council of 15 January 2008 on the definition, description, presentation, labelling and the protection of geographical indications of spirit drinks and repealing Council Regulation (EEC) No 1576/89 the only allowed source for spirits production are raw materials of agricultural origin.

Our calculations show different biogas yields according to different agricultural resources when the biogas yield per thousand litres was estimated according to the already available research outcomes. We can clearly see that the type of agricultural sources used for spirits production has a significant impact on the biogas production potential. Based on data collected by the Ministry of Agriculture and Rural Development of the Slovak Republic (2021), Slovak distilleries use corn as the main source for spirits production. More than $95 \%$ of all spirits produced by the Slovak spirits industry uses corn for spirits production. This has also a positive effect on the potential of biogas production by these enterprises because corn has the highest biogas yields among all agricultural sources used for spirits production. We followed the potential biogas production using the corn as a source for the production of spirits in our further investigation, based on the abovementioned findings.

There are different options distilleries have when it comes to the use of biogas produced within their premises. They can use the biogas directly for heating their distilling stills or sell it to third parties. The most efficient way occurs to be processing of biogas to electricity and selling it to the distribution

Table 2 Total and usable spent wash produced in spirits distilleries between years 2010 and 2019

\begin{tabular}{|l|c|c|c|} 
& Spirits production (I.a.) & Total spent wash production (tsd.I) & Usable spent wash production (tsd. I) \\
\hline $\mathbf{2 0 1 0}$ & $14,925,629$ & $149,256.29$ & $89,553.78$ \\
\hline $\mathbf{2 0 1 1}$ & $15,547,688$ & $155,476.88$ & $93,286.13$ \\
\hline $\mathbf{2 0 1 2}$ & $15,078,695$ & $150,786.95$ & $90,472.17$ \\
\hline $\mathbf{2 0 1 3}$ & $15,106,024$ & $151,060.24$ & $90,636.14$ \\
\hline $\mathbf{2 0 1 5}$ & $16,048,095$ & $160,480.95$ & $96,288.57$ \\
\hline $\mathbf{2 0 1 6}$ & $15,347,134$ & $153,471.34$ & $92,082.80$ \\
\hline $\mathbf{2 0 1 7}$ & $15,849,501$ & $158,495.01$ & $95,097.01$ \\
\hline $\mathbf{2 0 1 8}$ & $16,176,895$ & $161,768.95$ & $97,061.37$ \\
\hline $\mathbf{2 0 1 9}$ & $16,823,875$ & $168,238.75$ & $100,943.25$ \\
\hline
\end{tabular}


Table 3 Slovak spirits industry biogas production potential according to different agricultural sources between years 2010 and 2019

\begin{tabular}{|l|c|c|c|c|c|c|c|}
\hline & Usable spent wash production (tsd. I) & Sugar molasses $\left(\mathrm{m}^{3}\right)$ & Potatoes $\left(\mathrm{m}^{3}\right)$ & Wheat $\left(\mathrm{m}^{3}\right)$ & Rye $\left(\mathrm{m}^{3}\right)$ & Corn $\left(\mathrm{m}^{3}\right)$ \\
\hline $\mathbf{2 0 1 0}$ & $89,553.78$ & $2,686,613$ & $3,223,936$ & $3,403,043$ & $3,582,151$ & $4,029,920$ \\
\hline $\mathbf{2 0 1 1}$ & $93,286.13$ & $2,798,584$ & $3,358,301$ & $3,544,873$ & $3,731,445$ & $4,197,876$ \\
\hline 2012 & $90,472.17$ & $2,714,165$ & $3,256,998$ & $3,437,942$ & $3,618,887$ & $4,071,248$ \\
\hline $\mathbf{2 0 1 3}$ & $90,636.14$ & $2,719,084$ & $3,262,901$ & $3,444,173$ & $3,625,446$ & $4,078,626$ \\
\hline 2014 & $96,288.57$ & $2,888,657$ & $3,466,389$ & $3,658,966$ & $3,851,543$ & $4,332,986$ \\
\hline 2015 & $92,082.8$ & $2,762,484$ & $3,314,981$ & $3,499,147$ & $3,683,312$ & $4,143,726$ \\
\hline 2016 & $95,097.01$ & $2,852,910$ & $3,423,492$ & $3,613,686$ & $3,803,880$ & $4,279,365$ \\
\hline 2017 & $97,061.37$ & $2,911,841$ & $3,494,209$ & $3,688,332$ & $3,882,455$ & $4,367,762$ \\
\hline 2018 & $100,943.3$ & $3,028,298$ & $3,633,957$ & $3,835,844$ & $4,037,730$ & $4,542,446$ \\
\hline 2019 & $103,323.9$ & $3,099,718$ & $3,719,661$ & $3,926,309$ & $4,132,957$ & $4,649,577$ \\
\hline
\end{tabular}

Table 4 The energy potential of biogas production in spirits distilleries between years 2010 and 2019

\begin{tabular}{|l|c|c|c|c|} 
& Usable spent wash production (tsd. I) & Electricity production (kWh) & Heat production (kWh) & Total energy potential (kWh) \\
\hline $\mathbf{2 0 1 0}$ & $89,553.78$ & $13,768,893$ & $19,888,103$ & $33,656,996$ \\
\hline $\mathbf{2 0 1 1}$ & $93,286.13$ & $14,342,742$ & $20,716,983$ & $35,059,725$ \\
\hline $\mathbf{2 0 1 2}$ & $90,472.17$ & $13,910,096$ & $20,092,060$ & $34,002,156$ \\
\hline $\mathbf{2 0 1 3}$ & $90,636.14$ & $13,935,307$ & $20,128,475$ & $34,063,782$ \\
\hline $\mathbf{2 0 1 4}$ & $96,288.57$ & $14,804,368$ & $21,383,766$ & $36,188,133$ \\
\hline $\mathbf{2 0 1 5}$ & $92,082.8$ & $14,157,731$ & $34,607,480$ \\
\hline $\mathbf{2 0 1 6}$ & $95,097.01$ & $14,621,165$ & $35,740,308$ \\
\hline $\mathbf{2 0 1 7}$ & $97,061.37$ & $14,923,186$ & $21,119,143$ & $36,479,575$ \\
\hline $\mathbf{2 0 1 8}$ & $100,943.3$ & $21,555,389$ & $37,937,502$ \\
\hline 2019 & $103,323.9$ & $15,520,025$ & $22,417,477$ & $38,832,230$ \\
\hline
\end{tabular}

network. An obvious advantage is the state-guaranteed price and other support schemes available for the production of electricity in biogas plants.

However, biogas plants are not able to fully utilize the energy potential locked in the biogas produced within their own premises. This efficiency may differ in different biogas plants and processing techniques used in these facilities. Biogas plants utilized by spirits distilleries can be beneficial in two ways for these enterprises. The primary goal is the production of electricity using biogas in the observed biogas plants. There is about $36 \%$ efficiency estimate according to the available research (Gleixner, 2004). The total electricity production potential ranged from 13,768,893 kWh in 2010 to $15,886,053 \mathrm{kWh}$ in 2019 , according to our calculations.

The second energy source represents heat energy produced during the biogas production process. This heat energy can be directly used on the site during the distillation process. The efficiency is even higher at the level of $52 \%$ in this case. Substitution of the gas used for distillation columns heating has a positive economic and environmental effect. Distilleries are able to lower their production costs and improve their competitiveness in the national or global level. Substitution of gas by heat generated during biogas production can also significantly lower greenhouse production by distilleries. According to our calculations, distilleries could save from 19,888,103 kWh to $22,946,177 \mathrm{kWh}$ of energy otherwise gained from fossil fuels.

\section{Conclusions}

The Slovak spirits industry has a stable position within the alcoholic beverages market in the Slovak Republic. Despite the obvious decline in alcoholic beverages consumption, we observed a steady growth in production within the observed years. This growth has a positive effect on revenues within the industry but a negative effect on the environment. The spirits industry produces by far the most waste during production if we compare the production of all alcoholic beverages. In general, we can conclude that around 10\% (or even less) of processed raw material is transformed into the final product. The spirits industry is facing new challenges related to waste production and its reuse. Distilling enterprises will face new legislation reflecting various actions of the EU oriented on sustainable development, circular economy, and waste reduction. We decided to investigate biogas production potential within the Slovak distilling industry based on already available research regarding biogas yields from different agricultural sources. Creating biogas plants directly on the site can create positive synergic effects. Distilleries can sell electricity directly to the distribution network. On the other hand, distilleries can reuse heat energy generated during the biogas production by biogas plants. There is even higher energy gain from heat energy compared to electricity produced and sold to the distribution network. Our study unveiled the total combined energy potential of the biogas produced within the Slovak spirits industry from 33,656,996 kWh in 2010 to 38,832,230 kWh in 2019. Our research was strictly oriented on the general biogas production potential within the 
Slovak spirits industry. It is beyond the scope of this article to reveal the own potential of individual spirits producing companies, especially in relation to their annual production capacity. Further research developing a framework of biogas production potential within various spirits companies, especially in relations to their yearly production, is necessary.

\section{Acknowledgement}

This research paper was prepared in the frame of the Erasmus+ Jean Monnet Module project "Economic and Legal Basics of Entrepreneurship in Agrifood Industry" No. 600459-EPP-1-2018-1-SK-EPPJM0-MODULE.

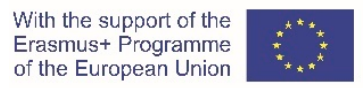

\section{References}

BARRIÈRE, Y. - COURTIAL, A. - CHATEIGNER-BOUTIN, A. L. - DENOUE, D. - GRIMAPETTENATI, J. 2016. Breeding maize for silage and biofuel production, an illustration of a step forward with the genome sequence. In Plant Science, vol. 242, 2016, pp. 310-329.

BIO-ENERGY PLANTS transform whisky distillery sector. 2016. In Filtration + Separation, vol. 53, 2016, no. 6, pp. 18-19. https://doi.org/10.1016/s0015-1882(16)30250-6

ČERYOVÁ, D. - TURČEKOVÁ, N. - BEŇUŠ, 0. - VALENTíNY, F. 2019. Renewable energy sources and economic efficiency of biogas plant. In Business and entrepreneurial economics BEE, 2019, pp. 96-101.

DATABASE - EUROSTAT. 2021. Eurostat. https://ec.europa.eu/eurostat/web/main/data/ database

DHOTE, L. - KUMAR, S. - SINGH, L. - KUMAR, R. 2020. A systematic review on options for sustainable treatment and resource recovery of distillery sludge. In Chemosphere, vol. 263, 2020, pp. 128225. ISSN 0045-6535. https://doi.org/10.1016/j. chemosphere.2020.128225.

DUGUID, L. - STRACHAN, P. 2016. Sustainable Energy Using Anaerobic Digestion of ByProducts: Islay Whisky Industry Case Study.

EUR-Lex - 52020DC0098 - EN - EUR-Lex. 2021. European Commission. https://eur-lex. europa.eu/legal-content/EN/TXT/?qid=1583933814386\&uri=COM:2020:98:FIN

GLEIXNER, A. J. 2004. Brennerei und Biogas. Referat zur Infoveranstaltung "Bioethanolund Energieerzeugung in mittelständischen landwirtschaftlichen Brennereien", veranstaltet vom Verband Bayer. München : Landw. Brennereien eG, 2004.

GRÉRG, V. - UHER J. 1974. Výroba Lihovin. Praha : Nakladatelství technické literatury, n. p. 1974.

HARTMANN, W. - SCHWARZ, P. 2018. Die 100 besten Obstsorten für die Brennerei. Ulmer Eugen Verlag, 2018.

HIRANI, A. H. - JAVED, N. - ASIF, M. - BASU, S. K. - KUMAR, A. 2018. A review on firstand second-generation biofuel productions. In Biofuels: Greenhouse Gas Mitigation and Global Warming, New Delhi: Springer, 2018, pp. 141-154.

JENIÍČEK, P. - SÝKORA, M. 1994. Možnosti produkce bioplynu z melasových výpalků a odpadních vod lihovarů. In Kvasný průmysl, vol. 40, 1994, pp. 12.

KOVAL, V. - MIKHNO, I. - HAJDUGA, G. - GASKA, K. 2019. Economic efficiency of biogas generation from food product waste. In E3S Web of Conferences, EDP Sciences, vol. 100, 2019, pp. 00039.
LAJDOVÁ, Z. - KAPUSTA, J. - BIELIK, P. 2017. Assessing interdependencies between food and energy prices: The case of biodiesel in Germany. In AGRIS on-line Papers in Economics and Informatics, vol. 9, 2017, pp. 51-59.

LORENZ, D. - MORRIS, D. 1995. How much energy does it take to make a gallon of ethanol? Washington, DC: Institute for Local Self-Reliance, 1995.

MAKUTENAS, V. - MICEIKIENE, A. - SVETLANSKÁ, T. - TURČEKOVÁ, N. - ŠAUČIŪNAS, T. 2018. The impact of biofuels production development in the European Union. In Agricultural Economics, vol. 64, 2018, no. 4, pp. 170-185

MINISTRY OF AGRCILUTURE and Rural Development of the Slovak Republic. 2021. Annual report on management of food business enterprises. Bratislava: Ministry of Agrciluture and Rural Development of the Slovak republic, 2021.

NETO, J. M. - KOMESU, A. - DA SILVA MARTINS, L. H. - GONÇALVES, V. 0. 0. - DE OLIVEIRA, J. A. R. - RAI, M. 2019. Third generation biofuels: an overview. In Sustainable Bioenergy, 2019, pp. 283-298. https://doi.org/10.1016/b978-0-12817654-2.00010-1

NYDRLE, A. 1974. Lihovarství Zemedelské. Alberta Malíre na král. Czech Republic, Prague, $1974,168 \mathrm{p}$.

O'SHEA, R. - LIN, R. - WALL, D. M. - BROWNE, J. D. - MURPHY, J. D. 2020. Using biogas to reduce natural gas consumption and greenhouse gas emissions at a large distillery. In Applied Energy, vol. 279, 2020, pp. 115812.

PIMENTEL, D. - PATZEK, T. W. 2005. Ethanol production using corn, switchgrass, and wood; biodiesel production using soybean and sunflower. In Natural resources research, vol. 14, 2005, no. 1, pp. 65-76.

RABEYA, T. - JEHADIN, F. - ASAD, M. A. - AYODELE, 0. 0. - ADEKUNLE, A. E. - ISLAM, M. S. 2020. Alkali and Intensified Heat Treatment of Corn Stalk for Bioethanol Production. In Sugar Tech, 2020, pp. 1-8.

REGULATION no. 110/2008 of the European Parliament and of the Council of 15 January 2008 on the definition, description, presentation, labelling and the protection of geographical indications of spirit drinks and repealing Council Regulation (EEC) no. 1576/89 the only allowed source for spirits production are raw materials of agricultural origin.

STATISTA. 2021. Spirits - Worldwide. https://www.statista.com/outlook/cmo/alcoholicdrinks/spirits/worldwide

STEHLÍK, K. 1981. Treatment and utilization of distillery and yeast factory effluents by irrigation. In Kvasny Prumysl, vol. 27, 1981, no. 1), pp. 253-258. https://doi.org/10.18832/kp1981048

THE DISTILLERS embracing sustainable practices. 2021. The Spirits Business. https://www. thespiritsbusiness.com/2021/03/the-distillers-embracing-sustainable-practises/

\section{Contact address}

Ondrej Beňuš, Slovak University of Agriculture in Nitra, Faculty of Economics and Management, Department of Economics, Tr. Andreja Hlinku 2, 949 76, Nitra, Slovak Republic; ㅍㅛㅛ +421 37641 45 83; e-mail: ondrej.benus@uniag.sk 